\title{
ТЕХНИКО-ЭКОНОМИЧЕСКАЯ ЦЕЛЕСООБРАЗНОСТЬ ПРИМЕНЕНИЯ МИКРОСВАЙ ИЗ ЖЕЛЕЗОБЕТОНА ДЛЯ ФУНДАМЕНТОВ МАЛОЭТАЖНОГО ДОМОСТРОЕНИЯ
}

\author{
(c) 2021 Преснов Олег Михайлович \\ кандидат технических наук, доцент \\ Сибирский федеральный университет, Россия, Красноярск \\ E-mail: OPresnov@sfu-kras.ru \\ (C) 2021 Костылев Петр Николаевич \\ студент экспертизы и управления недвижимостью \\ Сибирский федеральный университет, Россия, Красноярск \\ E-mail: qpeterkosq@gmail.com \\ (c) 2021 Лукина Лидия Андреевна \\ студент экспертизы и управления недвижимостью \\ Сибирский федеральный университет, Россия, Красноярск \\ E-mail: lida.lukina.2015@mail.ru
}

\begin{abstract}
Микросваи - это один из современных и надежных способов устройства фундаментов в малоэтажном домостроении. Применение железобетонных микросвай в качестве фундаментов при строительстве малоэтажного домостроения является технически и экономически целесообразным.
\end{abstract}

Ключевые слова: микросваи, фундаменты, экономическая эффективность.

Фундамент - нижняя (подземная) часть здания, предназначенная для принятия нагрузок от надземных конструктивных элементов и передачи этих нагрузок на основание (грунт). Отсюда следует, что прочность и надежность фундамента является залогом эксплуатационной надежности здания. Само понятие «фундамент» пришло к нам из Древнего Рима и в переводе с латинского fundamentum означает основание, опору.

Древняя мудрость, высказанная итальянским зодчим Андреа Палладио: «Закладывай крепко основу для здания, ибо она подобна охране», в настоящее время является особо актуальной.

От правильного применения типа фундамента, качества его проектирования и возведения зависит надежность, долговечность, безопасность здания.

Но выбор фундамента должен быть обоснован не только этими параметрами. Немаловажную роль играет и экономическая сторона вопроса. Неоправданный перерасход материальных ресурсов, завышение массы фундамента, трудоемкости его возведения приводит к удорожанию строительных работ и стоимости здания в целом, как результат, увеличению себестоимости $1 \mathrm{~m}^{2}$ площади здания - фактор далеко нема- ловажный в жилищном строительстве.

Для малоэтажного здания стоимость строительства фундаментов составляет 15-20\% от общей стоимости объекта, а продолжительность возведения фундаментов, как наиболее трудоемкого процесса, составляет 20-25\% времени приходящегося на весь объем работ.

Поэтому принятие наиболее рационального типа фундамента является весьма актуальной проблемой малоэтажного домостроения.

Какой тип фундамента применять зависит от многих факторов: гидрогеологического состояния грунтов строительной площадки, уровня грунтовых вод, глубины промерзания, нагрузок на фундамент, требований к сроку эксплуатации здания и др. Универсального решения этого вопроса нет.

Конструкция фундамента всегда уникальна.

Строительная практика за всю свою многовековую историю накопила немалый опыт в сооружении фундаментов и их конструкций.

Среди различных типов устройства фундаментов малоэтажных зданий, таких как ленточный, сплошной, столбчатый, отдельной группой выделяют применение микросвай различных конструкций.

Микросваи - небольшие сваи сечением, как правило, до 300 мм, которые изготавливаются 
из железобетона (цементного раствора и металла), длиной, в зависимости от условий применения, от 2 до 5 метров.

Железобетонные микросваи - это один из современных и надежных способов устройства фундаментов в малоэтажном домостроении.

По способу изготовления и заглублению в грунт различают микросваи забивные и набивные.

По форме поперечного сечения: прямоугольного, квадратного, круглого, трапециевидного и др.

Забивные микросваи изготавливаются заранее и погружаются в грунт за счет механического нагружения - с помощью молота, вибрации или вдавливания. Для погружения микросвай как правило используют специальную сваебойную технику облегченного типа.

Забивные железобетонные микросваи изготавливают на заводах из бетона M300, M500 с усиленным армированием оголовка и наконечника. Несущая способность 1 сваи (сечением140x150 мм длиной 4200 мм) - около 8 тонн. Железобетонные сваи могут быть с ненапрягаемой и предварительно напряженной арматурой.

Такие микросваи незаменимы в районах с повышенным уровнем грунтовых вод, на проблемных грунтах, в местах с твердыми глинистыми слоями, а также экономически оправданы на насыпных участках в т.ч. с большими перепадами высот.

Набивные (буронабивные) микросваи устраивают из бетона (железобетона) путем заполнения скважины в грунте.

Технология включает следующие операции: создается арматурный каркас, который в дальнейшем устанавливается в пробуренную скважину и заливается бетон.

Для буронабивного свайного фундамента опалубкой является сам грунт, либо в качестве опалубки можно применить трубы из металла или асбоцемента, имеющие соответствующий диаметр.

Для увеличения несущей способности микросваи могут устраиваться с расширением в нижней части (пятой). Уширения в полости скважины выполняются специальными механизмами, в результате чего ниже забоя скважины образуется шаровидное пространство, заполняющееся в последствии бетонной смесью.

Уширение ствола и пяты микросваи, может быть выполнено:
- путем дополнительной разработки грунта в основании микросваи механическим способом;

- путем втрамбовки бетона ниже пяты микросваи;

- путем установки расширяемого тела.

Размер, шаг установки микросвай, глубину заложения подбирают по расчёту.

Буронабивные микросваи с успехом могут применятся в стесненных условиях и вблизи существующих зданий (плотной застройки).

В сухих связных грунтах в том числе просадочных, для малоэтажных зданий рекомендуется использовать набивные микросваи, устраиваемые в уплотненных скважинах методом вытрамбовывания, пробивки или продавливания.

Фундаменты на микросваях имеют ряд преимуществ перед традиционными (ленточными, столбчатыми) фундаментами:

- высокая несущая способность в плохих геологических условиях;

- работы организуются в любое время года, независимо от погоды и географической привязки объекта;

- доступность проведения работ поблизости от зелёных насаждений и в районе локализации сети подземных коммуникаций;

- возможность строительства на сложных грунтах и рельефах без проведения дополнительных работ.

Оценка вариантов проектных решений фундаментов производится путем сравнительного анализа их технико-экономических показателей:

- стоимостных показателей (приведенные затраты в руб., сметная стоимость возведения фундаментов, капитальные вложения в материально-техническую базу строительства и др.);

- натуральных показателей (продолжительность возведения, затраты труда, расход основных материалов и др.).

В качестве единицы измерения принимаются: $1 \mathrm{~m}^{2}$ общей площади здания, 1 фундамент, 1 м стен, единица расчетной нагрузки от здания или сооружения и т.п.

При оценке проектных решений фундаментов сравниваемые варианты должны отвечать условиям сопоставимости:

- проектные решения рассчитывают на одинаковые нагрузки, для одних и тех же грунтовых условий; 
- стоимостные показатели должны определяться для условий одного и того же района строительства, в едином уровне цен на рассматриваемые конструкции и материалы, с применением единой сметно-нормативной базы.

В результате обзора литературных источни- ков [1] в таблицах 1 и 2 приведены сравнительные расчетные данные технико-экономических показателей различных типов фундаментов. Сравнительный анализ проводился с использованием принципа сопоставимости.

Таблица 1. Сравнительные технико-экономические показатели ленточных и набивных свайных фундаментов (на $1 \mathrm{~m}^{2}$ общей площади жилого здания)

\begin{tabular}{|l|c|c|c|c|}
\hline \multicolumn{1}{|c|}{ Наименование } & Единица изм. & $\begin{array}{c}\text { Ленточные фунда- } \\
\text { менты * }\end{array}$ & $\begin{array}{c}\text { Набивные свайные } \\
\text { фундаменты }\end{array}$ & Отклонения (\%) \\
\hline Приведенные затраты & руб. & 4,48 & 2,58 & $-42,4 \%$ \\
\hline Себестоимость & руб. & 3,86 & 2,29 & $-40,67 \%$ \\
\hline Затраты туда & чел.-дн & 0,154 & 0,089 & $-42,2 \%$ \\
\hline Расход материалов: & & & & $-37,3 \%$ \\
\hline бетон & м $^{3}$ & 0,059 & 0,037 & $-36,0 \%$ \\
\hline цемент & кг & 13,97 & 8,94 & $-53,3 \%$ \\
\hline сталь & кг & 1,2 & 0,56 & \\
\hline
\end{tabular}

* - железобетонный ленточный фундамент: плита монолитная, стены сборные блоки;

** - набивные сваи: в буровых скважинах с вытрамбованной уширенной пятой.

Таблица 2. Сравнительные технико-экономические показатели различных типов фундаментов под стены, колонны, рамы (на $100 \mathrm{~m}^{2}$ площади основания)

\begin{tabular}{|c|c|c|c|c|c|c|c|c|c|c|c|}
\hline \multirow[b]{3}{*}{ Наименование } & \multirow[b]{3}{*}{$\begin{array}{l}\text { Ед. } \\
\text { Изм. }\end{array}$} & \multicolumn{4}{|c|}{ Под стены } & \multicolumn{3}{|c|}{ Под колонны } & \multicolumn{3}{|c|}{ Под рамы } \\
\hline & & \multirow[b]{2}{*}{ 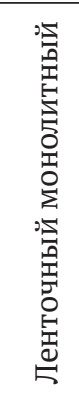 } & \multirow[b]{2}{*}{ 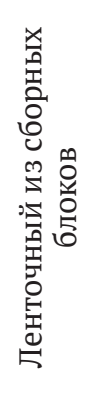 } & \multicolumn{2}{|c|}{ Свайный } & \multirow[b]{2}{*}{ 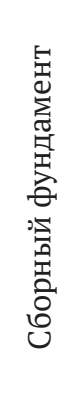 } & \multicolumn{2}{|c|}{ Свайный } & \multirow[b]{2}{*}{ 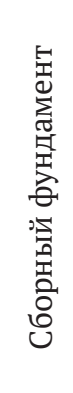 } & \multicolumn{2}{|c|}{ Свайный } \\
\hline & & & & 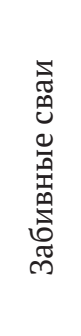 & 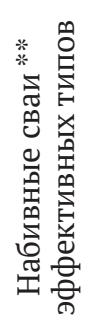 & & 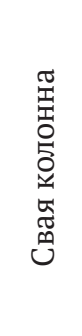 & 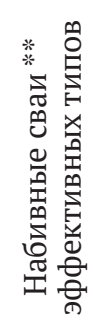 & & 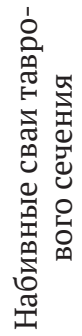 & 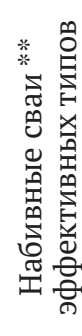 \\
\hline 1 & 2 & 3 & 4 & 5 & 6 & 7 & 8 & 9 & 10 & 11 & 12 \\
\hline $\begin{array}{l}\text { Приведенные } \\
\text { затраты }\end{array}$ & руб. & 290 & 587 & 240 & $\begin{array}{c}209- \\
240\end{array}$ & 187 & 196 & $\begin{array}{l}94- \\
150\end{array}$ & 181 & 154 & $\begin{array}{c}121- \\
127\end{array}$ \\
\hline Себестоимость & руб. & 238 & 462 & 213 & $\begin{array}{l}189- \\
213\end{array}$ & 160 & 170 & $\begin{array}{l}86- \\
136\end{array}$ & 153 & 136 & $\begin{array}{c}113- \\
118\end{array}$ \\
\hline Затраты труда & $\begin{array}{c}\text { чел.- } \\
\text { дн. }\end{array}$ & 16,0 & 23.5 & 10,1 & $\begin{array}{l}8,9- \\
13.6\end{array}$ & 6,9 & 5,7 & $\begin{array}{c}3,4- \\
6.2\end{array}$ & 13,7 & 6,4 & $\begin{array}{c}3,6- \\
4,2\end{array}$ \\
\hline $\begin{array}{l}\text { Объем механизи- } \\
\text { рованных земля- } \\
\text { ных работ }\end{array}$ & $M^{3}$ & 29,5 & 17,5 & 2,2 & 2,2 & 25,3 & 0 & 0 & 70,1 & 1,0 & 1,0 \\
\hline $\begin{array}{l}\text { Объем ручных зем- } \\
\text { ляных работ }\end{array}$ & $\mathrm{M}^{3}$ & 2,0 & 9,1 & 1,6 & 1,6 & 1,7 & 1,2 & 1,2 & 4,6 & 0,5 & 0,5 \\
\hline \multicolumn{12}{|l|}{ Расход матер.: } \\
\hline бетона & $\mathrm{M}^{3}$ & 10,5 & 10,2 & 3,7 & $\begin{array}{c}3,0- \\
3,7\end{array}$ & 1,83 & 1,78 & $\begin{array}{c}1,39- \\
2,36\end{array}$ & 1,85 & 1,22 & $\begin{array}{l}1,5- \\
1,59\end{array}$ \\
\hline цемента & Кг & 2450 & 2000 & 800 & $\begin{array}{c}670- \\
800\end{array}$ & 423 & 605 & $\begin{array}{c}296- \\
537\end{array}$ & 537 & 413 & $\begin{array}{c}430- \\
456\end{array}$ \\
\hline
\end{tabular}

*- расчетные технико-экономические показатели приведены для строительства в условиях Московской области при нагрузке на 1 м фундаментов под стены 50-60 кН, нагрузке на одну опору под колонны 180-200 кН, распоре рам 150-160 кН. Основание - глинистые грунты с консистенцией $0,3-0,5$.

** - в группе эффективных типов набивных свай рассмотрены фундаменты в вытрамбованных котлованах, пробитых скважинах и сваи с уширением. 
Анализируя данные, приведённые в таблицах, можно сделать вывод:

- применение микросвай в качестве фундаментов позволяет сократить расход материалов в $1,5-3,5$ раза;

- возведение свайных фундаментов под стены, колонны зданий экономически эффективно по стоимостным показателям (в т.ч. приведенным затратам, себестоимости) по сравнению с традиционными ленточными и столбчатыми фундаментами;

- проведение работ по устройству микросвай наименее трудозатраты (не требует проведения большого объема земляных работ перед строительством фундамента).

Таким образом, применение железобетонных микросвай в качестве фундаментов при строительстве малоэтажного домостроения является технически и экономически целесообразным.

\section{Библиографический список}

1. Руководство по выбору проектных решений фундаментов НИИОСП им. Н. М. Герсеванова, НИИЭС, ЦНИИПроект Госстроя СССР.-М: Стройиздат, 1984.-192 с.

2. ГОСТ Р 57342-2016 «Микросваи. Правила производства работ» // Режим доступа: https://gost.ru.

3. Конюхов Д.С. Строительство городских подземных сооружений мелкого заложения М.: Архитектура-С, $2005.304 \mathrm{c}$. 